\title{
Assessing the Efficacy of A Marine Reserve to Protect Sharks With Differential Habitat Use
}

Cesar Peñaherrera-Palma ( $\sim$ cesar.penaherrera@migramar.org )

MigraMar

\section{Alistair Hobday}

CSIRO Ocean and Atmosphere

\section{Alex Hearn}

Universidad San Francisco de Quito

\section{Eduardo Espinoza}

Galapagos National Park

\section{George Shillinger}

Upwell

James Ketchum

Pelagios-Kakunjá

\section{A. Klimley}

University of California, Davis

\section{Stewart Frusher}

University of Tasmania

G. Fischer

Ocearch

Jayson Semmens

University of Tasmania

\section{Research Article}

Keywords: Galapagos, habitat preference, home range, marine protected area, satellite telemetry, shark.

Posted Date: December 15th, 2020

DOI: https://doi.org/10.21203/rs.3.rs-124555/v1

License: (c) (i) This work is licensed under a Creative Commons Attribution 4.0 International License. Read Full License 


\section{Abstract}

Spatial management through the implementation of marine protected areas is one strategy to limit the extraction of sensitive marine species. Understanding the area used by marine life is thus a key step towards the evaluation of the management framework and efficacy of a protected area. To provide information of the protective coverage of the Galapagos Marine Reserve (GMR), we assessed the habitat utilization distribution (UD) of hammerhead and blacktip sharks in the GMR. Fifteen hammerhead sharks and 27 blacktip sharks were tagged with SPOT and SPLASH satellite tags in the north and south-central regions of the GMR between 2007 and 2012. Our results show nearly $90 \%$ of hammerhead shark's UD was enclosed by the reserve boundary during the cold season (June-October), yet this decreased to only $~ 30 \%$ with the advent of the warm season (December-April). Conversely, blacktip sharks' UD was $100 \%$ enclosed by the reserve boundaries in all seasons. Season and depth were the most important environmental parameters defining the UD of hammerhead sharks; whilst year and eddy kinetic energy were the most important parameters for blacktip sharks. These findings suggest the size of the GMR may be effective for blacktip sharks but seasonally effective for hammerhead sharks.

\section{Introduction}

Despite the controversy around the magnitude of species' declines 12 , and the ecological effect such declines may produce3'4, it is accepted that overfishing is the major cause of population decline among cartilaginous fishes $5^{\prime} 6$. Sharks are mostly caught as by-catch in fisheries targeting teleost fish species, such as tuna and marlin7. As such, sharks are being harvested under management regulations more suited to species with higher intrinsic rebound potential89. To avoid the collapse of shark populations, management should focus on reducing fishing mortality to the population's rebuilding rate8.

Spatial closures are considered to be an important tool to aid the management of fisheries targeting commercially and ecologically sensitive species10,11. Generally, spatial management is carried out through the implementation of fixed marine protected areas (MPA), but it can also be implemented by seasonal12 or dynamic13 spatial closures. MPAs are increasingly becoming popular tools to limit the extraction of sensitive fish species and buffer the effects of fisheries in surrounding marine ecosystems 14,15 . While there is substantial evidence supporting the implementation of MPAs in maintaining the biomass and diversity of coastal fish species 16,17 , their potential to protect highly mobile species is still the subject of debate18-20. Shark movements can exceed MPA boundaries and national jurisdictions $21 \cdot 22$, making them vulnerable when migrating to unmanaged open-fishing areas23. For wide-ranging species, MPAs should encompass a significant proportion of their life stages and movements, with emphasis on reproducing adults9. Unfortunately, the lack of supporting evidence on the recovery of highly mobile fish species still limits a wider implementation of these reserves 15.

The Galapagos Marine Reserve (GMR) is the second largest MPA in the Eastern Tropical Pacific Ocean (ETP), covering approximately $138000 \mathrm{~km}^{2}$ of the pelagic environment surrounding the Galapagos Islands24. It lies in the confluence of three major currents, with marked seasonal gradients in current strength, sea surface temperature and productivity25. The reserve was created in 1998 with the main aim of protecting all the coastal marine ecosystems and a significant proportion of the pelagic waters surrounding the archipelago24. Theoretical approaches modelling the food-web interactions in the pelagic (open-water) Galapagos ecosystems, suggested that the pelagic and coastalpelagic shark species would be expected to have increased in biomass since the creation of the GMR26. However, contrasting the ecological knowledge of dive guides against empirical information about the relative sharks abundance demonstrates that this increases might only apply to certain coastal species, such as the blacktip shark (Carcharhinus limbatus)27. Pelagic species such as the scalloped hammerhead shark (Sphyrna lewini) are reported to 
have declined by $50 \%$ in their relative abundance across the GMR27, which was also reported for other MPAs of the ETP28'29. Given the unknown spatial scale of the home range of shark species around Galapagos, there are concerns the size of the reserve may not adequately protect sensitive species like the critically endangered scalloped hammerhead shark30.

This study aimed to assess the protective coverage of the GMR over the home range of the scalloped hammerhead shark and the blacktip shark. Specifically, this research is aimed to i) compare the environmental preferences of hammerhead and blacktip sharks in the GMR; ii) evaluate their spatial and temporal habitat utilization in relation to the size of the GMR; and iii) characterize the factors influencing the selection of core areas (preferred habitat) within their utilization distributions.

\section{Results}

Relocation information was obtained from eight hammerheads (males $=6$, females $=2$ ), tracked for 5 to 148 days (average 48 days); and 18 blacktip (males $=2$, females $=16$ ) sharks tracked for 18 to 512 days (average 102 days) (Table 1, Appendix 2). The hammerhead sharks varied from 1.42 to $2.35 \mathrm{~m}$ in total length (mean 1.97; SD 0.34). The total number of transmissions per individual ranged between 5 and 91 (mean 37; SD 30) and the average time gap between successive relocations varied from 0.1 to 4.5 days (mean 2.2; SD 1.6). Blacktip sharks ranged from $1.96 \mathrm{~m}$ to $2.54 \mathrm{~m}$ in total length (mean 2.12; SD 0.13). The total number of transmissions per individual averaged 129.8, with a maximum of 422 . The average time gap between successive relocations ranged from 0.4 up to 4.7 days (mean 1.3 ; SD $1.1)$. 
Table 1

Satellite tracked scalloped hammerhead and blacktip sharks summary data. The averaged gap refers to the average time (in days) between two consecutive relocations. Distance from tagging site refers to the linear distance (in $\mathrm{Km}$ ) between the tagging and the farthest location sharks travelled. Tagging bioregion: N, north; SC, south-central region.

\begin{tabular}{|c|c|c|c|c|c|c|c|c|c|}
\hline Tag ID & Sex & Size & $\begin{array}{l}\text { Tagging } \\
\text { bioregion }\end{array}$ & $\begin{array}{l}\text { Tagging } \\
\text { date }\end{array}$ & $\begin{array}{l}\text { Last } \\
\text { transmission }\end{array}$ & $\begin{array}{l}\text { Total } \\
\text { days }\end{array}$ & $\begin{array}{l}\text { Total } \\
\text { transmission }\end{array}$ & $\begin{array}{l}\text { Averaged } \\
\text { gap } \\
\text { (days) }\end{array}$ & $\begin{array}{l}\text { Distance } \\
\text { from } \\
\text { tagging }\end{array}$ \\
\hline \multicolumn{10}{|c|}{ Hammerhead sharks } \\
\hline $\mathrm{HH} 1$ & $M$ & 2.25 & $\mathrm{~N}$ & $\begin{array}{l}02-11- \\
2007\end{array}$ & $26-01-2008$ & 85 & 55 & 1.6 & 586.9 \\
\hline $\mathrm{HH} 2$ & M & 1.94 & $\mathrm{~N}$ & $\begin{array}{l}24-07- \\
2008\end{array}$ & 16-09-2008 & 54 & 13 & 4.5 & 95.8 \\
\hline $\mathrm{HH} 3$ & M & 1.75 & $\mathrm{~N}$ & $\begin{array}{l}24-07- \\
2008\end{array}$ & 07-08-2008 & 14 & 5 & 3.4 & 25.9 \\
\hline $\mathrm{HH} 4$ & M & 2.24 & $\mathrm{~N}$ & $\begin{array}{l}\text { 24-07- } \\
2008\end{array}$ & $19-12-2008$ & 148 & 58 & 2.6 & 244.3 \\
\hline $\mathrm{HH} 5$ & M & 2.35 & $\mathrm{~N}$ & $\begin{array}{l}13-03- \\
2009\end{array}$ & 01-04-2009 & 19 & 6 & 3.8 & 339 \\
\hline $\mathrm{HH} 6$ & M & 2.18 & $\mathrm{~N}$ & $\begin{array}{l}14-03- \\
2009\end{array}$ & 20-04-2009 & 37 & 30 & 1.3 & 310.2 \\
\hline $\mathrm{HH} 7$ & $\mathrm{~F}$ & 1.42 & SC & $\begin{array}{l}13-12- \\
2011\end{array}$ & 07-01-2012 & 25 & 91 & 0.3 & 21.6 \\
\hline HH8 & $\mathrm{F}$ & 1.6 & SC & $\begin{array}{l}\text { 06-02- } \\
2012\end{array}$ & $11-02-2012$ & 5 & 39 & 0.1 & 144.4 \\
\hline \multicolumn{10}{|c|}{ Blacktip sharks } \\
\hline BK1 & $\mathrm{F}$ & 2.04 & $\mathrm{~N}$ & $\begin{array}{l}27-07- \\
2006\end{array}$ & $16-08-2006$ & 20 & 5 & 4.7 & 292.7 \\
\hline BK2 & M & 2.14 & $\mathrm{~N}$ & $\begin{array}{l}27-07- \\
2006\end{array}$ & 16-08-2006 & 20 & 7 & 3 & 258 \\
\hline BK3 & M & 2.08 & $\mathrm{~N}$ & $\begin{array}{l}\text { 02-08- } \\
2006\end{array}$ & 26-08-2006 & 24 & 15 & 2 & 19.4 \\
\hline BK4 & $\mathrm{F}$ & 2.21 & $\mathrm{~N}$ & $\begin{array}{l}06-08- \\
2006\end{array}$ & $22-10-2006$ & 77 & 60 & 1.5 & 35.9 \\
\hline BK5 & $\mathrm{F}$ & 2.1 & SC & $\begin{array}{l}26-11- \\
2011\end{array}$ & 26-12-2011 & 30 & 38 & 0.8 & 73.4 \\
\hline BK6 & $F$ & 2.15 & SC & $\begin{array}{l}29-11- \\
2011\end{array}$ & $19-12-2011$ & 20 & 12 & 2.3 & 57.4 \\
\hline BK7 & $\mathrm{F}$ & 2 & SC & $\begin{array}{l}18-12- \\
2011\end{array}$ & 05-01-2012 & 18 & 40 & 0.5 & 87.9 \\
\hline BK8 & $F$ & 2 & SC & $\begin{array}{l}01-11- \\
2013\end{array}$ & $01-12-2013$ & 30 & 52 & 0.6 & 64.2 \\
\hline BK9 & $\mathrm{F}$ & 2.54 & SC & $\begin{array}{l}26-01- \\
2014\end{array}$ & $19-06-2014$ & 144 & 249 & 0.5 & 23.5 \\
\hline BK10 & $\mathrm{F}$ & 2.03 & SC & $\begin{array}{l}26-01- \\
2014\end{array}$ & 07-08-2014 & 193 & 409 & 0.4 & 61.6 \\
\hline
\end{tabular}




\begin{tabular}{|c|c|c|c|c|c|c|c|c|c|}
\hline Tag ID & Sex & Size & $\begin{array}{l}\text { Tagging } \\
\text { bioregion }\end{array}$ & $\begin{array}{l}\text { Tagging } \\
\text { date }\end{array}$ & $\begin{array}{l}\text { Last } \\
\text { transmission }\end{array}$ & $\begin{array}{l}\text { Total } \\
\text { days }\end{array}$ & $\begin{array}{l}\text { Total } \\
\text { transmission }\end{array}$ & $\begin{array}{l}\text { Averaged } \\
\text { gap } \\
\text { (days) }\end{array}$ & $\begin{array}{l}\text { Distance } \\
\text { from } \\
\text { tagging }\end{array}$ \\
\hline BK11 & $\mathrm{F}$ & 2.13 & SC & $\begin{array}{l}28-01- \\
2014\end{array}$ & $31-08-2014$ & 215 & 422 & 0.5 & 74.6 \\
\hline BK12 & $\mathrm{F}$ & 2.03 & SC & $\begin{array}{l}28-01- \\
2014\end{array}$ & $30-03-2014$ & 61 & 55 & 1.1 & 32.3 \\
\hline BK13 & $\mathrm{F}$ & 2.13 & SC & $\begin{array}{l}28-01- \\
2014\end{array}$ & 28-06-2014 & 151 & 221 & 0.7 & 60.8 \\
\hline BK14 & $\mathrm{F}$ & 2.15 & SC & $\begin{array}{l}29-01- \\
2014\end{array}$ & $10-05-2014$ & 101 & 106 & 0.9 & 33.9 \\
\hline BK15 & $\mathrm{F}$ & 1.96 & SC & $\begin{array}{l}31-01- \\
2014\end{array}$ & 24-04-2014 & 83 & 172 & 0.5 & 58.1 \\
\hline BK16 & $\mathrm{F}$ & 2.29 & SC & $\begin{array}{l}01-02- \\
2014\end{array}$ & 13-03-2014 & 40 & 34 & 1.2 & 30.4 \\
\hline BK17 & $\mathrm{F}$ & 2.13 & SC & $\begin{array}{l}01-02- \\
2014\end{array}$ & 28-06-2015 & 512 & 288 & 1.7 & 37.5 \\
\hline BK18 & $\mathrm{F}$ & 2.03 & SC & $\begin{array}{l}05-02- \\
2014\end{array}$ & $21-05-2014$ & 105 & 151 & 0.7 & 24.9 \\
\hline
\end{tabular}

Hammerhead shark travel distance from the tagging location was significantly greater than for blacktip sharks (t-test $p$ $=0.004$ ). The average distance from the tagging location was $221 \mathrm{~km}$ (SD 191) for hammerhead sharks and $73.7 \mathrm{~km}$ (SD 76.2) for blacktip sharks. Hammerhead sharks travelled beyond the reserve boundaries although they did not migrate between the north and south of the GMR. In contrast, blacktip sharks remained within the reserve, particularly north of Santa Cruz Island, and migrated between regions within the GMR (Fig. 1; Supporting Information).

The traversed environmental conditions significantly differed between species (Appendix 3). Hammerhead sharks mainly inhabited waters with an average depth of $1560 \mathrm{~m}, \mathrm{SST}$ of $25.1^{\circ} \mathrm{C}$, relatively low chlorophyll a concentration (mean $0.336 \mathrm{mg} \mathrm{m}^{-3}$ ) and relatively high EKE (mean $132.2 \mathrm{~m}^{2} \mathrm{~s}^{2}$ ). Conversely, tagged blacktip sharks preferred areas with average depths of $140 \mathrm{~m}$, SST of $25.7^{\circ}$, chlorophyll a concentrations of $0.682 \mathrm{mg} \mathrm{m}^{-3}$ and EKE of $34.7 \mathrm{~m}^{2} \mathrm{~s}^{2}$. For hammerhead sharks, seasonal environmental conditions varied between individuals with significant differences in all environmental variables except EKE. Increasing variability in the environmental conditions (depth, SST and chlorophyll) traversed by hammerhead sharks while moving away from the tagging locations during the warm season caused this outcome. Transition and colder season relocations were characterized by more stable environmental conditions. Despite most relocations from blacktip sharks being around Santa Cruz Island, the traversed environmental conditions per season significantly varied for all environmental variables (Appendix 3 ).

The estimated UD area was significantly greater for hammerhead sharks than for blacktip sharks (Mood median test $p$ < 0.01). Hammerheads individual UD area varied from 912 to $21868 \mathrm{~km}^{2}$ (median 6110), whilst blacktips' estimated UD area varied from 754 to $11155 \mathrm{~km}^{2}$ (median 1993). Estimations of seasonal UD area did not yield significant differences within the same species (for hammerhead sharks, Mood test $p>0.74$; for blacktip sharks, Mood test $p<$ 0.12 . The area used by hammerhead sharks was confined around Darwin and Wolf Islands during the cold months, and extended away from the GMR boundaries in warmer seasons (Fig. 2). Approximately $90 \%$ of the estimated UD area of all hammerhead sharks was confined within the GMR during the cold season; $65 \%$ in the transition period, and $30 \%$ in the warm season. Conversely, blacktip sharks' UD was completely confined within the reserve across all seasons (Fig. 2). 
Season, year, depth and chlorophyll a were the only environmental predictors that statistically influenced $(p<0.01)$ the probability of the UD of hammerhead sharks (Table 2). The best-fit model explained $51.7 \%\left(R^{2}=0.493\right)$ of the total deviance and was obtained from the additive effects of depth, season, year and SST. Depth and season were the most important factors, followed by the year and SST. Despite the importance of chlorophyll $a$ as a single factor, it did not have a major additive effect in the final model. Partial response curves suggest hammerhead sharks remain during the colder months (June - October) in areas shallower than $1000 \mathrm{~m}$ where SST is lower than $25^{\circ} \mathrm{C}$ (Fig. 3). In the case of blacktip sharks, all environmental predictors had a statistically significant influence on their probability of UD, yet not all contributed to the top-fitted models (Table 2). The best-fit model for this species explained $64.7 \%\left(R^{2}=0.493\right)$ of the total deviance and was built with four variables. Year and EKE were the most important factors influencing the model, followed by SST and season. Partial response curves suggest blacktip sharks travelled farther distances during 2006 to 2012, but were staying closer to the core UD area towards 2015 (Fig. 3). GAM results suggest that core UD area of this species is characterized by EKE lower than $50 \mathrm{~m}^{2} \mathrm{~s}^{2}$, seafloor depth less than $500 \mathrm{~m}$ and temperatures lower than $22^{\circ} \mathrm{C}$. 
Table 2

Top models for the effect of environmental covariates on the utilization distribution of both hammerhead and blacktip sharks. Chl: Chlorophyll a; SST: seas surface temperature; EKE, eddy kinetic energy. Single asterisks $\left({ }^{*}\right)$ indicate significant single predictors. Double asterisk (**) indicate best-fit models.

\begin{tabular}{|c|c|c|c|}
\hline Model $^{b}$ & AIC & BIC & $\begin{array}{l}\text { Smoothing } \\
\text { criterion }\end{array}$ \\
\hline
\end{tabular}

Hammerhead sharks

One variable

\begin{tabular}{lccccc} 
Season* & -191.7 & -177.0 & 0.030 & 0.265 & 27.0 \\
\hline Depth* & -154.1 & -121.8 & 0.035 & 0.179 & 19.8 \\
\hline Year* & -139.1 & -117.0 & 0.036 & 0.128 & 14.0 \\
\hline Chl* & -134.2 & -105.3 & 0.027 & 0.176 & 20.8 \\
EKE & -106.7 & -91.1 & 0.041 & 0.022 & 2.9 \\
SST & -105.1 & -89.0 & 0.041 & 0.016 & 2.4
\end{tabular}

Top models

\begin{tabular}{|c|c|c|c|c|c|}
\hline Depth + Season + Year & -289.1 & -232.8 & 0.022 & 0.490 & 51.3 \\
\hline Depth + Season + Year + SST** & -289.7 & -230.0 & 0.022 & 0.493 & 51.7 \\
\hline Depth + Season + Year + EKE & -289.7 & -228.7 & 0.022 & 0.494 & 51.9 \\
\hline $\begin{array}{l}\text { Depth + Season + Year + SST + } \\
\text { EKE }\end{array}$ & -290.0 & -225.5 & 0.022 & 0.495 & 52.2 \\
\hline
\end{tabular}

$\begin{array}{llllll}\text { Full model } & -213.6 & -137.6 & 0.018 & 0.509 & 56.9\end{array}$

Blacktip sharks

One variable

\begin{tabular}{lccccc} 
Year* & -1979.0 & -1938.7 & 0.025 & 0.495 & 49.6 \\
\hline EKE* & -1358.2 & -1297.0 & 0.033 & 0.335 & 33.8 \\
\hline SST* $^{*}$ & -990.2 & -928.5 & 0.038 & 0.230 & 23.3 \\
\hline Depth* & -809.8 & -770.1 & 0.041 & 0.167 & 16.9 \\
\hline Season* & -584.2 & -561.2 & 0.046 & 0.082 & 8.2 \\
Chl* & -328.2 & -293.1 & 0.048 & 0.033 & 3.6
\end{tabular}

Top models

\begin{tabular}{llllll} 
Year + EKE + Depth & -2643.5 & -2506.3 & 0.019 & 0.619 & 62.2 \\
\hline Year+ EKE + Depth + SST & -2764.8 & -2579.3 & 0.018 & 0.639 & 64.4 \\
\hline Year + EKE + Depth + Season & -2676.2 & -2527.1 & 0.019 & 0.625 & 62.8 \\
\hline Year + EKE + Depth + SST + & -2782.0 & -2584.8 & 0.018 & 0.642 & 64.7 \\
Season & & & & 0.643 & 65.0 \\
\hline Year+ EKE + Depth + SST + Chl & -1906.3 & -1724.3 & 0.018 &
\end{tabular}




\begin{tabular}{|cccccl|}
\hline Model $^{\text {b }}$ & AIC & BIC & $\begin{array}{l}\text { Smoothing } \\
\text { criterion }\end{array}$ & $\mathbf{R}^{2}$ & $\begin{array}{l}\text { Explained deviance } \\
(\%)\end{array}$ \\
\hline Full model & -1924.6 & -1724.8 & 0.018 & 0.632 & 64.0 \\
\hline
\end{tabular}

\section{Discussion}

Our results highlight the value of a MPA to protect shark species with coastal habitats and strong site fidelity, yet they also show that MPA size is less effective in the case of migratory coastal-pelagic species. While blacktip sharks movements were totally encompassed by the GMR size, hammerhead shark movements were mostly protected by the reserve boundary only during the cold season.

Regardless the number of tagged individuals differed between species and between tagging locations, there was a significative difference of the travelled distance from the tagging location between hammerhead sharks $(\sim 221 \mathrm{Km})$ and blacktip sharks ( $74 \mathrm{Km})$. Furthermore, all blacktip sharks (tagged in the north and south) moved within the GMR boundary all year round, while hammerhead sharks displayed broader movements with preference for oceanic waters, including the individual tagged around the southern islands. The lack of population structure in both hammerhead and blacktip sharks within the GMR 31, along with our findings suggest the tagging location should not have affected the obtained results.

The scalloped hammerhead shark is found all year round in the GMR, particularly in higher relative abundance during the cold season (June-October) at the islands of Darwin and Wolf. Klimley and Nelson 32 hypothesized this species uses the central refuging strategy 33 , by using oceanic islands and seamounts as a refuge, from where they can take advantage of nearby foraging areas. Long-term passive acoustic tracking has shown hammerhead sharks to display strong site fidelity to the islands of Darwin and Wolf3435. This study provides further support by showing an islandcentred core UD around Wolf and Darwin Island. Results also suggest there is a strong seasonal component in the extension of the UD of hammerheads, with individuals progressively leaving the protection of the reserve with the advent of the warmer months. Hammerhead sharks' long distance migrations between MPAs of the ETP have been reported to occur also during the warm season35, yet it is still unknown which factors trigger such behaviour. Pelagic species are known to change their geographic distribution between environmental seasons according to changing currents36.37, foraging38, reproductive39 or parturition needs. Given tracked hammerhead sharks were mostly males, reproductive needs are less likely to be responsible for the observed shift in UD. The marked seasonality in the oceanographic conditions of the GMR25 could be playing a major role in the spatial extension of the UD in hammerheads around the GMR by influencing the vertical and horizontal distribution of their preferred prey items. Bessudo, et al. 40 reported that hammerhead sharks around Malpelo and Cocos Islands undertake deep "yo-yo" dives $(>100 \mathrm{~m})$ in waters away from the islands during the warm season, whilst the same individuals preferred surface waters $(0-10 \mathrm{~m})$ near the islands during the colder season.

The blacktip shark is also a cosmopolitan species sharing a similar distribution to hammerhead sharks among tropical and subtropical oceans of the world41. There is a considerable amount of work available on the occurrence, demography and environmental preferences of juvenile blacktip sharks at nursery grounds in coastal and estuarine bays $42 \cdot 43$. Nevertheless, there is no available information regarding adult behavioural ecology and their habitat use. This study presents the first description on the UD of blacktip sharks and supports previous suggestions of strong site fidelity and residency for this species 44 . Areas of shallow water ( $<500 \mathrm{~m}$ deep) and low EKE in the centre of the southcentral region of the GMR were preferred by both sexes of blacktip sharks. A possible explanation for the strong site fidelity may be philopatry of adults to their nursery grounds. Keeney, et al. 45 conducted genetic analysis and reported that female blacktip sharks display strong philopatry to their nursery grounds found around the Caribbean and North- 
western Atlantic region. The occurrence of important nursery grounds in the south central GMR46 further supports this for the GMR. The presence of feeding grounds in the area, either via prey availability (e.g. whitetip reef sharks47, sealions48), or food provisioning from ships or fishers49, could be also influencing the strong fidelity observed around Santa Cruz Island.

The reported habitat use in addition to the recently reported relative abundance increase 27 and identified nursery grounds for blacktip sharks46 indicate that the GMR provides adequate protection for the different life history stages. By contrast, hammerhead sharks were reported to have declined by $50 \%$ within the GMR27, which in combination with our results suggest this species is not being effectively protected by this MPA. Although there are informal reports of juvenile hammerhead sharks, at present there is no scientifically assessed hammerhead nurseries within the GMR. This suggests only adult and sub-adults individuals are benefiting from the reserve's protective coverage, particularly during the cold season. If fully functional nursery grounds were present, we'd expect UDs, especially of females, to show seasonal movement towards pupping grounds within the GMR. The apparent recovery of blacktip sharks and decline of hammerheads reflect these differing levels of protection in Galapagos. A similar scenario for both species has been reported for Cocos Island28, a smaller MPA also located the ETP.

The inadequacy of the reserve size to protect hammerhead sharks is of particular concern given this species' current global endangered status30. A revision of the management of this species in the ETP suggested the creation of several small non-take MPAs (which include the existent MPAs of the region) enclosed in a large special marine managed area from Galapagos to Costa Rica50. Such a special managed area would allow a considerably reduced fishing effort and should be equal in size to the Exclusive Economic Zones of the countries with national jurisdiction in the region. Achieving this complex spatial zoning, however, would require high levels of national and international agreements and would have important economic implications for the industrial fishing operations in the area. Also, this will not stop interactions between fisheries and hammerhead sharks whenever they leave the small non-take MPAs.

Alternatively, dynamic spatial closures extending the current fixed GMR boundaries could reduce the susceptibility of hammerhead sharks to fishing operations. Examples of this are currently in place to manage the longline fisheries on the east coast of Australia. The near real time dynamic spatial allocation of take and non-take areas reduces the interactions between fishing fleets and pelagic by-catch species 13,51. This management approach could be applied to create seasonal buffer zones and extend the boundaries of the GMR to reduce the capture susceptibility of hammerhead sharks. The reported seasonality in fisheries catches around the GMR by Martinez-Ortiz, et al. 52 supports the feasibility of this alternative, their study found that there was a seasonal difference in species caught, where larger fish including sharks made the majority of the catches in warmer seasons and considerably less catches in colder seasons.

A further in-depth evaluation of the habitat preferences of hammerhead sharks and commercial teleost fishes is recommended, particularly focused on increasing the number of tagged individuals and total tracked days. This evaluation will help to determine the level of habitat overlap between commercial fish species and hammerhead sharks, and the environmental factors managers could use to adopt seasonal spatial closures around the GMR and the neighbouring MPAs of Cocos and Malpelo Islands. Habitat preferences of hammerhead sharks should be evaluated with a larger number of individuals per season, as recommended when assessing the implementation of dynamic spatial closures37. The implementation of dynamic spatial closures will allow seasonal fishing (economic) and decreased shark mortalities (biological) out of the GMR, while maintaining the ecological balance of seamounts (ecological) and support to the valuable dive tourism industry (economic) within the GMR. If implemented, this scenario could provide global lessons for managing oceanic species, particularly those of high conservation concern such as the endangered hammerhead shark. 


\section{Methods}

Data collection. The Galapagos Marine Reserve (GMR) is located approximately $1000 \mathrm{~km}$ east from the continental coast of Ecuador, South America (Fig. 1). Field trips were carried out from 2006 to 2014 to tag hammerhead and blacktip sharks in the north (Darwin and Wolf Islands) and south central (around Santa Cruz Island) regions of the GMR.

Ten hammerhead sharks were tagged in the north and five in the south-central regions of the GMR between 2007 and 2012. Similarly, seven blacktip sharks were tagged in the north and 20 in the south central GMR between 2006 and 2014. All sharks were caught from a small boat using barbless circle hooks and nylon lines, with pieces of skipjack (Katsuwonus pelamis) or wahoo (Acanthocybium solandri) as bait. Once hooked, sharks were allowed to calm down prior to slowly being towed to a mother-vessel located less than 10 minutes away. Sharks were either brought on board using a sling and hydraulic crane, or drawn onto a platform that was lowered into the water and subsequently raised above sea level. On deck, sharks were immobilized, their eyes covered with a wet cloth, and seawater pumped continuously across their gills. All sharks were measured and sexed, after which either SPOT 5 or SPLASH (Wildlife Computers - Redmond, USA) satellite transmitter tags were attached to the dorsal fin with nuts, bolts and rubber gaskets. These tags were configured to send location data to Argos satellites whenever a shark's dorsal fin breached the water surface.

Data was filtered to eliminate spurious relocations by screening out values beyond sensor specifications (latitude and longitude) or with low relocation quality (A, B, Z types), and unattainable speeds by animals greater than $2.25 \mathrm{~ms}^{-1}$, following Weng, et al. 53 and Ketchum 50, and using the package "trip" implemented within the R software environment. We used the Spatial Dynamics Ocean Data Explorer (SDODE) interface54 to match each filtered relocation with remote sensing data on sea surface temperature (SST), chlorophyll a (Chl), eddy kinetic energy (EKE) and depth (more information available in Appendix 1).

Data analysis. Habitat utilization was estimated by calculating the probability utilization distribution (UD) using the Brownian Bridge kernel method (BBKM)55 implemented in the "adehabitat" family package56 within the R software environment. The BBKM is dependent on two parameters: $i$ ) the imprecision of each relocation; and, ii) the Brownian Motion Variance factor55. To estimate the first parameter, we used the mean error radius provided by the Argos satellite telemetry location information. We estimated the mean error radius for both species and seasons separately. The Brownian motion variance parameter was estimated by using a maximum likelihood approach developed by Horne, et al. 55. The analysis was placed in a grid system consisting of $25 \mathrm{~km}^{2}$ cells around the GMR. The analysis was run per species and per season (cold: June-October, warm: December-April, transition: May and November). To test differences between the species' environmental preferences and UD areas, parametric (e.g. Student's t-test) and nonparametric tests (e.g. Mood's median test, Kruskal-Wallis test by ranks) were used.

The habitat environmental preferences in the UDs of each shark species were assessed following Papastamatiou, et al. 39. To characterise the areas where all individuals from the same species coincided while migrating across the GMR, we overlayed the UDs of all sharks of the same species, calculated the cumulative UD values per cell, and then transformed the cumulative UD to a fraction of 1 (by dividing each value by the maximum cumulative value obtained in the final grid). We used a stepwise Generalized Additive Model (GAM) to model the single and additive effect of depth, SST, Chl, EKE, seasons and year (predictive variables) over the cumulative UD (response variable). GAMs were built under a Gaussian family distribution with identity links and smooth splines. Model selection criteria were based on the adjusted Akaike's Information Criterion (AICC) and Bayesian Information Criterion (BIC) values to take into account differences in effective sample size and lack of fit57,58. We followed a manual step-wise model construction 
and selection process. We built an initial model with predictors independent from each other, and then selected the best model using the lowest AIC and BIC. We continued building more complex models by adding each additional predictor considered one at a time. We favoured the parsimony principle and chose simpler over more complex models whenever we obtained competing models with similar AIC and BIC results.

\section{Ethics Statement.}

All research methods were carried out in accordance with relevant guidelines and regulations approved by the University of Tasmania Animal Ethics Committee (permit No. A13641), by the Institutional Animal Care and Use Committee of the University of California - Davis (permit number IACUC PROTOCOL \#16022), by the Directorate of the Galapagos National Park (research permit No. PC-60-13); and in compliance with the ARRIVE guidelines (www.arriveguidelines.org).

\section{Declarations}

\section{Acknowledgements}

This project was funded by the Secretariat of Higher Education, Science, Technology and Innovation (formerly known as SENESCYT) of the Ecuadorean Government, the QMS top-up scholarship, the Holsworth Wildlife Research Endowment; The Offield Family Foundation; WWF Prince Bernard Scholarships; Linblad Expeditions; National Geographic Society; Galapagos Conservation Trust; Swiss Friends of Galapagos, Conservation International; Block Lab of Stanford University, Marisla Foundation; Ocearch Foundation, and the Charles Darwin Foundation. We are indebted to the captains and crew of the research and patrolling vessels of the Directorate of the Galapagos National Park, Ocearch R/V, Queen Mabel M/Y, and Arrecife M/Y, and to the dive guides and volunteers who assisted our fieldwork in all its stages.

\section{Author contributions}

Authors CPP, JTK, GLS, GCF, APK and EE contributed in research planning, fundraising, data collection and manuscript writing; CPP, ARH, AJH, JMS, and SF contributed in data collection, data analysis and manuscript writing.

\section{Additional information}

\section{Competing interests}

The author(s) declare no competing interests.

\section{References}

1. Burgess, G. H. et al. Is the collapse of shark populations in the Northwest Atlantic Ocean and Gulf of Mexico real? Fisheries 30, 19-26, doi:10.1577/1548-8446(2005)30[19:itcosp]2.0.co;2 (2005).

2. Baum, J. K. \& Myers, R. A. Shifting baselines and the decline of pelagic sharks in the Gulf of Mexico. Ecol. Lett. 7, 135-145, doi:10.1111/j.1461-0248.2003.00564.x (2004).

3. Myers, R. A., Baum, J., Shepherd, T. D., Powers, S. P. \& Peterson, C. H. Cascading effects of the loss of apex predatory sharks from a coastal ocean. Science 315, 1846-1850 (2007).

4. Grubbs, R. D. et al. Critical assessment and ramifications of a purported marine trophic cascade. Scientific Reports 6, 20970, doi:10.1038/srep20970 (2016). 
5. Dulvy, N. K. et al. Extinction risk and conservation of the world's sharks and rays. Elife 3, e00590, doi:10.7554/eLife.00590 (2014).

6. Ferretti, F., Worm, B., Britten, G. L., Heithaus, M. R. \& Lotze, H. K. Patterns and ecosystem consequences of shark declines in the ocean. Ecololgy Letters 13, 1055-1071, doi:10.1111/j.1461-0248.2010.01489.x (2010).

7. Barker, M. J. \& Schluessel, V. Managing global shark fisheries: suggestions for prioritizing management strategies. Aquat. Conserv.: Mar. Freshwat. Ecosyst. 15, 325-347, doi:10.1002/aqc.660 (2005).

8. Worm, B. et al. Global catches, exploitation rates, and rebuilding options for sharks. Mar. Policy 40, 194-204, doi:10.1016/j.marpol.2012.12.034 (2013).

9. Au, D. W., Smith, S. E. \& Show, C. in Intrinsic rates of increase in pelagic elasmobranchs (eds M. Camhi, E. K. Pikitch, \& E. A. Babcock) Ch. 26., (John Wiley \& Sons, 2009).

10. White, T. D. et al. Assessing the effectiveness of a large marine protected area for reef shark conservation. Biol. Conserv. 207, 64-71, doi:10.1016/j.biocon.2017.01.009 (2017).

11. Halpern, B. S. \& Warner, R. R. Marine reserves have rapid and lasting effects. Ecol. Lett. 5, 361-366, doi:10.1046/j.1461-0248.2002.00326.x (2002).

12. Wolff, M. Tropical waters and their living resources: ecology, assessment and management. 343 (Verlag H. M. Hauschild $\mathrm{GmbH}, 2009)$.

13. Hobday, A. J., Hartog, J. R., Spillman, C. M., Alves, O. \& Hilborn, R. Seasonal forecasting of tuna habitat for dynamic spatial management. Can. J. Fish. Aquat. Sci. 68, 898-911, doi:10.1139/f2011-031 (2011).

14. Caddy, J. F. \& Agnew, D. J. An overview of recent global experience with recovery plans for depleted marine resources and suggested guidelines for recovery planning. Rev. Fish Biol. Fish. 14, 43-112, doi:10.1007/s11160004-3770-2 (2005).

15. Ward-Paige, C. A., Keith, D. M., Worm, B. \& Lotze, H. K. Recovery potential and conservation options for elasmobranchs. J. Fish Biol. 80, 1844-1869, doi:10.1111/j.1095-8649.2012.03246.x (2012).

16. Edgar, G. J. et al. Global conservation outcomes depend on marine protected areas with five key features. Nature 506, 216-220, doi:10.1038/nature13022 (2014).

17. Halpern, B. S. The impact of marine reserves: Do reserves work and does reserve size matter? Ecol. Appl. 13, S117S137 (2003).

18. Game, E. T. et al. Pelagic protected areas: the missing dimension in ocean conservation. Trends Ecol. Evol. 24, 360-369, doi:10.1016/j.tree.2009.01.011 (2009).

19. Game, E. T. et al. Pelagic MPAs: The devil you know. Trends Ecol. Evol. 25, 63-64, doi:10.1016/j.tree.2009.09.002 (2010).

20. Kaplan, D. M., Chassot, E., Gruss, A. \& Fonteneau, A. Pelagic MPAs: the devil is in the details. Trends Ecol. Evol. 25, 62-63; author reply 63-64, doi:10.1016/j.tree.2009.09.003 (2010).

21. Hearn, A. et al. Simple criteria to determine detachment point of towed satellite tags provide first evidence of return migrations of whale sharks (Rhincodon typus) at the Galapagos Islands, Ecuador. Animal Biotelemetry 1, 11, doi:10.1186/2050-3385-1-11 (2013).

22. Block, B. A. et al. Tracking apex marine predator movements in a dynamic ocean. Nature 475, 86-90, doi:10.1038/nature10082 (2011).

23. Queiroz, N. et al. Global spatial risk assessment of sharks under the footprint of fisheries. Nature, doi:10.1038/s41586-019-1444-4 (2019).

24. Danulat, E. \& Edgar, G. Reserva Marina de Galápagos. Línea Base de la Biodiversidad. (Fundación Charles Darwin y Parque Nacional Galápagos, 2002). 
25. Palacios, D. M. Seasonal patterns of sea-surface temperature and ocean color around the Galapagos: regional and local influences. Deep-Sea Research // 51, 43-57 (2004).

26. Wolff, M., Peñaherrera-Palma, C. \& Krutwa, A. in The role of science for conservation (eds M. Wolff \& M. Gardener) (Routledge, 2012).

27. Peñaherrera-Palma, C. et al. Evaluating abundance trends of iconic species using local ecological knowledge. Biol. Conserv. 225, 197-207, doi:10.1016/j.biocon.2018.07.004 (2018).

28. White, E. R., Myers, M. C., Flemming, J. M. \& Baum, J. K. Shifting elasmobranch community assemblage at Cocos Island-an isolated marine protected area. Conserv. Biol. 29, 1186-1197, doi:10.1111/cobi.12478 (2015).

29. Soler, G. A., Bessudo, S. \& Guzmán, A. Long term monitoring of pelagic fishes at Malpelo Island, Colombia. Latin American Journal of Conservation 3, 28-37 (2013).

30. Rigby, C. L. et al. in The IUCN Red List of Threatened Species 2019 Vol. Version e.T39385A2918526 2 (International Union for the Conservation of Nature, 2019).

31. Hearn, A. R. et al. in Galapagos Marine Reserve: a dynamic socio-ecological system (eds Judith Denkinger \& Luis Vinueza) 23-59 (Springer, 2014).

32. Klimley, A. \& Nelson, D. R. Diel movement patterns of the scalloped hammerhead shark (Sphyrna lewini) in relation to El Bajo Espiritu Santo: a refuging central-position social system. Behav. Ecol. Sociobiol. 15, 9 (1984).

33. Hamilton, W. J. \& Kenneth, E. F. W. Refuging. Annu. Rev. Ecol. Syst. 1, 263-286 (1970).

34. Hearn, A., Ketchum, J., Klimley, A. P., Espinoza, E. \& Penaherrera, C. Hotspots within hotspots? Hammerhead shark movements around Wolf Island, Galapagos Marine Reserve. Mar. Biol. 157, 1899-1915, doi:10.1007/s00227-0101460-2 (2010).

35. Ketchum, J. T. et al. Inter-island movements of scalloped hammerhead sharks (Sphyrna lewini) and seasonal connectivity in a marine protected area of the Eastern Tropical Pacific. Mar. Biol. 161, 939-951, doi:10.1007/s00227-014-2393-y (2014).

36. Hartog, J. R., Hobday, A. J., Matear, R. \& Feng, M. Habitat overlap between southern bluefin tuna and yellowfin tuna in the east coast longline fishery - implications for present and future spatial management. Deep Sea Research Part II: Topical Studies in Oceanography 58, 746-752, doi:10.1016/j.dsr2.2010.06.005 (2011).

37. Hobday, A. J., Hartog, J. R., Timmiss, T. \& Fielding, J. Dynamic spatial zoning to manage southern bluefin tuna (Thunnus maccoyii) capture in a multi-species longline fishery. Fish. Oceanogr. 19, 243-253, doi:10.1111/j.13652419.2010.00540.x (2010).

38. Reilly, S. B. Seasonal changes in distribution and habitat differences among dolphins in the Eastern Tropical Pacific. Mar. Ecol. Prog. Ser. 66, 1-11, doi:10.3354/meps066001 (1990).

39. Papastamatiou, Y. P. et al. Telemetry and random-walk models reveal complex patterns of partial migration in a large marine predator. Ecology 94, 2595-2606, doi:10.1890/12-2014.1 (2013).

40. Bessudo, S. et al. Vertical and Horizontal movements of the scalloped hammerhead shark (Sphyrna lewini) around Malpelo and Cocos Islands (Tropical Eastern Pacific) using satellite telemetry. Bol. Invest. Mar. Cost. 40, 91-106 (2012).

41. Compagno, L. J. V., Dando, M. \& Fowler, S. Sharks of the world. (Princeton University Press, 2005).

42. Heupel, M. R., Carlson, J. K. \& Simpfendorfer, C. A. Shark nursery areas: concepts, definitions, characterization and assumptions. Mar. Ecol. Prog. Ser. 337, 287-297 (2007).

43. Knip, D., Heupel, M. \& Simpfendorfer, C. Sharks in nearshore environments: models, importance, and consequences. Mar. Ecol. Prog. Ser. 402, 1-11, doi:10.3354/meps08498 (2010). 
44. Dudley, S. F. J. \& Cliff, G. Sharks caught in the protective gill nets off Natal, South Africa. 7. The blacktip shark Carcharhinus limbatus (Valenciennes). South African Journal of Marine Science 13, 237-254. (1993).

45. Keeney, D. B., Heupel, M. R., Hueter, R. E. \& Heist, E. J. Microsatellite and mitochondrial DNA analyses of the genetic structure of blacktip shark (Carcharhinus limbatus) nurseries in the northwestern Atlantic, Gulf of Mexico, and Caribbean Sea. Mol. Ecol. 14, 1911-1923, doi:10.1111/j.1365-294X.2005.02549.x (2005).

46. Llerena, Y. et al. in Galapagos Report 2013-2014 (eds Linda J. Cayot, Desiree Cruz, \& Richard Knab) (GNPD, GCREG, CDF and GC, 2015).

47. Grove, J. S. \& Lavenberg, R. J. The fishes of the Galapagos Islands. (Standford University Press, 1998).

48. Salazar, S. in La Reserva Marina de Galápagos. Línea Base de la Biodiversidad. (eds E Danulat \& G. J. Edgar) (Fundación Charles Darwin / Parque Nacional Galápagos, 2002).

49. Acuña-Marrero, D. \& Peñaherrera-Palma, C. Interacciones entre tiburones y humanos en Galápagos: primera recopilación y análisis de ataques de tiburones registrados desde 1989. 20 (Fundación Charles Darwin, Puerto Ayora, Galapagos, Ecuador, 2011).

50. Ketchum, J. Movement patterns and habitat use of scalloped hammerhead sharks (Sphyrna lewini) in the Galapagos Islands: Implications for the design of marine reserves PhD dissertation thesis, University of California Davis, (2011).

51. Hobday, A. J. \& Hartmann, K. Near real-time spatial management based on habitat predictions for a longline bycatch species. Fish. Manage. Ecol. 13, 365-380, doi:10.1111/j.1365-2400.2006.00515.x (2006).

52. Martinez-Ortiz, J., Aires-da-Silva, A. M., Lennert-Cody, C. E. \& Maunder, M. N. The Ecuadorian artisanal fishery for large pelagics: Species composition and spatio-temporal dynamics. PLoS One 10, e0135136, doi:10.1371/journal.pone.0135136 (2015).

53. Weng, K. et al. Movements, behavior and habitat preferences of juvenile white sharks Carcharodon carcharias in the Eastern Pacific. Mar. Ecol. Prog. Ser. 338, 211-224 (2007).

54. Hartog, J. \& Hobday, A. SDODE: Spatial DynamicsOcean Data Explorer. User Guide v3. (CSIRO Marine and Atmospheric Research., Hobart, Tasmania, Australia., 2011).

55. Horne, J. S., Garton, E. O., Krone, S. M. \& Lewis, J. S. Analyzing animal movements using Brownian bridges. Ecology 88, 2354-2353 (2007).

56. Home Range Estimation in R: the adehabitatHR Package (Office national de la classe et de la faune sauvage Saint Benoist - 78610 Auffargis - France, 2015).

57. Guisan, A., Edwards Jr, T. C. \& Hastie, T. Generalized linear and generalized additive models in studies of species distributions: setting the scene. Ecol. Model. 157, 89-100, doi:http://dx.doi.org/10.1016/S0304-3800(02)00204-1 (2002).

58. Hastie, T. \& Tibshirani, R. Generalized Additive Models. Statistical Science 1, 297-310 (1986).

\section{Figures}




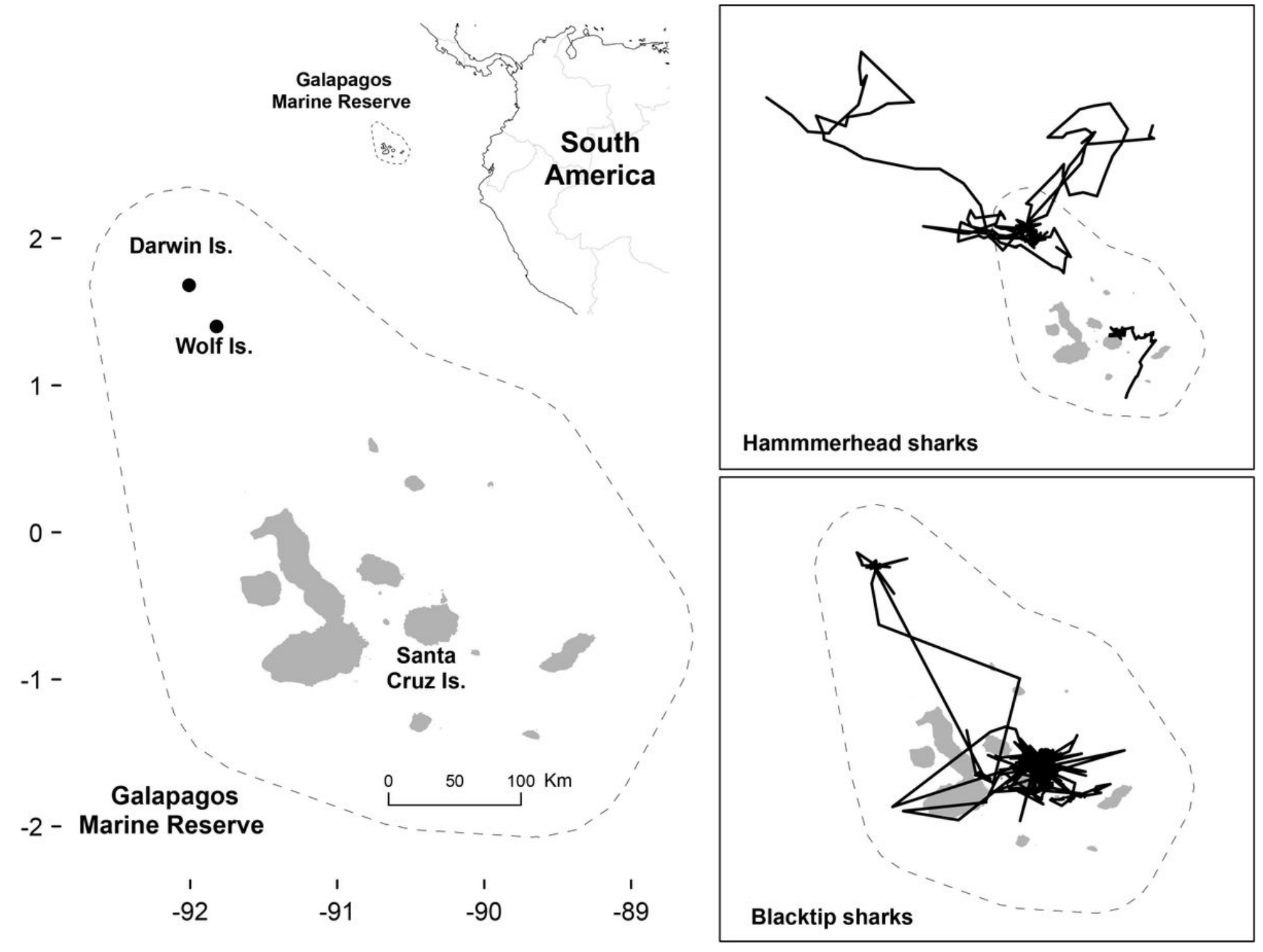

Figure 1

Galapagos Marine Reserve location and spatial extent of hammerhead sharks and blacktip sharks trajectories. Note: The designations employed and the presentation of the material on this map do not imply the expression of any opinion whatsoever on the part of Research Square concerning the legal status of any country, territory, city or area or of its authorities, or concerning the delimitation of its frontiers or boundaries. This map has been provided by the authors. 


\section{1}
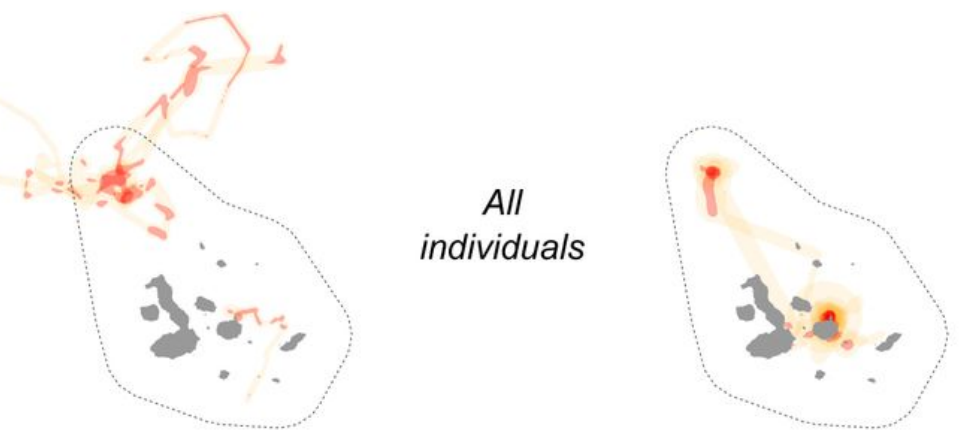

$95 \%$ probability
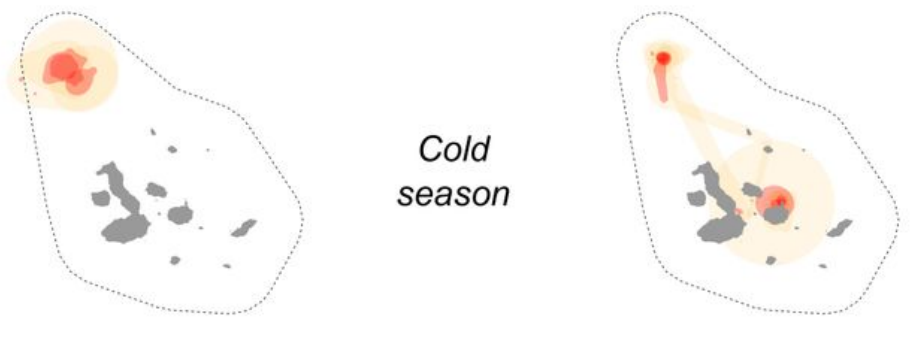

Islands
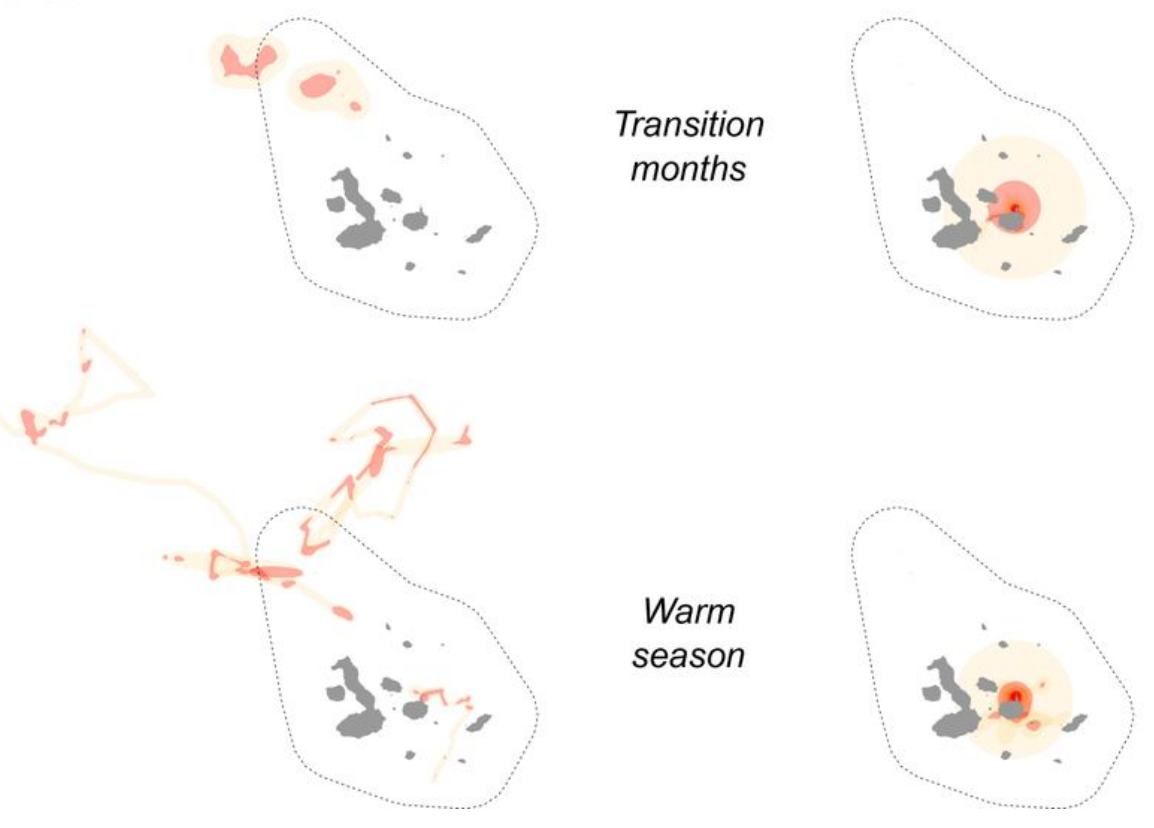

Figure 2

Hammerhead sharks and blacktip sharks habitat utilization distribution areas. 

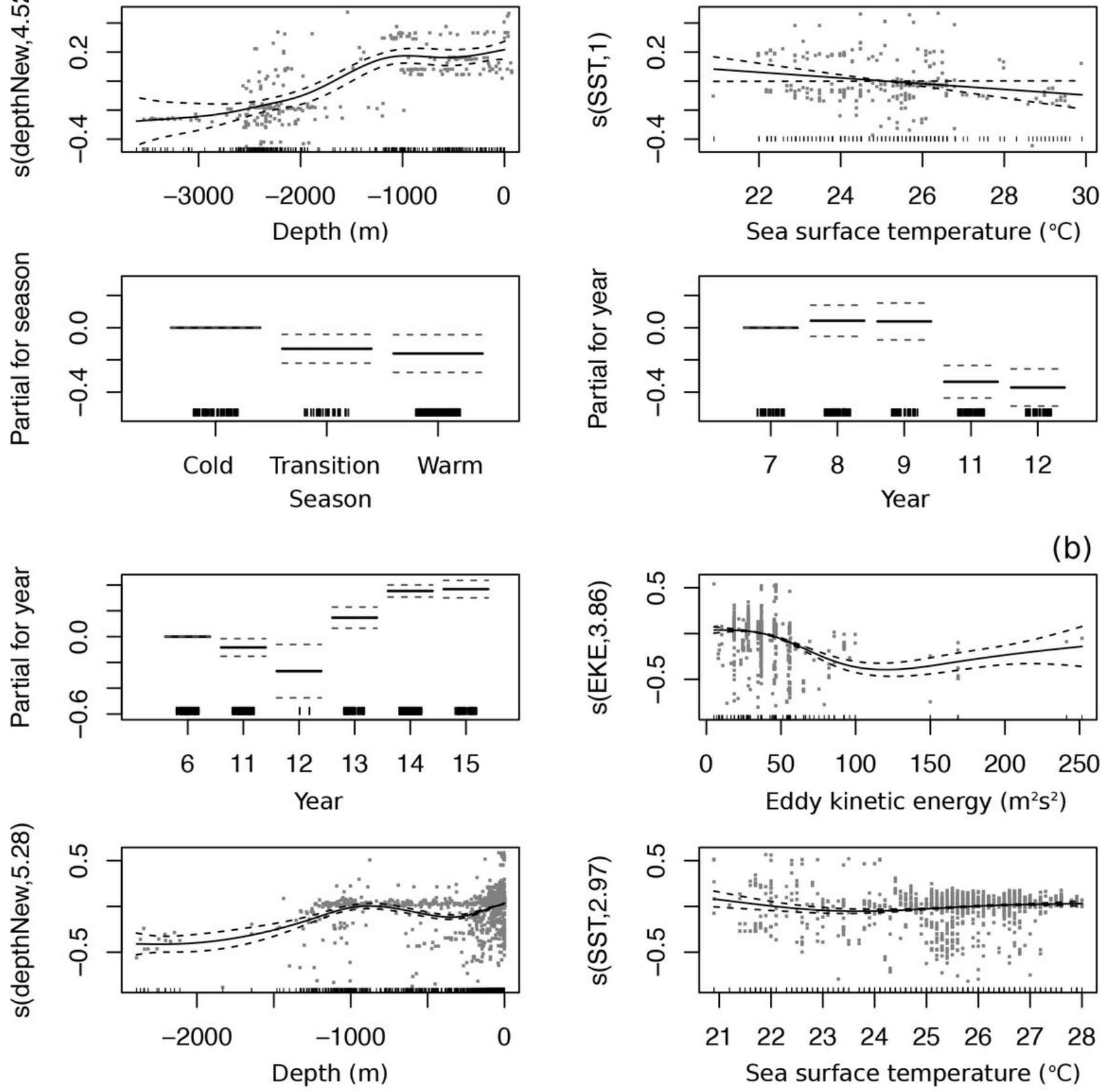

Figure 3

Partial residual plots for the GAM terms in the hammerhead shark (a) and blacktip shark (b) models. Dashed lines represent the $95 \%$ confidence limits; dots, the distribution of the partial residuals.

\section{Supplementary Files}

This is a list of supplementary files associated with this preprint. Click to download.

- Supplementarylnformation.pdf 